\title{
UV Spectroscopic Method for Determination of Vitamin C (Ascorbic Acid) Content in Different Fruits in South Gujarat Region
}

\author{
Anal Parimal Desai* and Shuchi Desai \\ Department of Pharmaceutical Quality Assurance, ROFEL Shri G M Bilakhia College of Pharmacy, India
}

Submission: July 29, 2019; Published: August 21, 2019

*Corresponding author: Anal Desai, Department of Pharmaceutical Quality Assurance, ROFEL Shri G M Bilakhia College of Pharmacy, India

\begin{abstract}
In the present study, determination of ascorbic acid content is determined in different fruits by using UV spectroscopy. In this method bromine water is added which oxidizes the ascorbic acid into dehydroascorbic acid. 2,4 dinitrophenyl hydrazine gives coupling reaction at $37^{\circ} \mathrm{C}$ temperature for 3 hours. After 3 hours solution is treated with 85\% H2SO4 which gives coloured complex and the absorbance was measured at $491 \mathrm{~nm}$. The content of vitamin C was found maximum in Black currant and minimum in Grapes.
\end{abstract}

Keywords: UV spectrophotometer; South Gujarat region; Ascorbic acid; Fruits

\section{Introduction}

Vitamins are organic compound (non-energy producing), which are essential for normal human metabolism that must be supplied in small quantities in the diet. The definition excludes the inorganic essential trace minerals and essential amino acids and fatty acids which are required in much larger quantities. Other substances needed for proper growth of microorganism or cells in culture are called growth factors. The different chemical forms and precursors of vitamin can be called its vitamers. The vitamins as a drug is necessary in the prevention and treatment of deficiency disease. Some vitamins do have major uses in pharmacological uses in pharmacological doses. Vitamin deficiency occur due to inadequate intake, malabsorption, increased tissue needs, increased excretion, certain genetic abnormalities and drug vitamin interaction. Vitamin C is a major water-soluble antioxidant. Generally, vitamin $C$ is 6 carbon organic acid with structural similarity to glucose. It acts as a potent reducing agent and its $\mathrm{l}$ form is generally more active. Citrus fruits are rich sources of vitamin C. According to recent research human milk contains more amount of vitamin C than the cow's milk. It is mostly absorbed from g.i.t and widely distributed extra and intra muscularly. Plasma concentration and total body store of vitamin c depends upon daily intake of ascorbic acid content food. The usual $60 \mathrm{mg} /$ day intake results in about $0.8 \mathrm{mg} / \mathrm{dl}$ in plasma and $1.5 \mathrm{~g}$ in the body as a whole. Increasing proportion are excreted in urine with higher intake. Body is not able to store more than $2.5 \mathrm{~g}$. It is partly oxidised to active (dehydroascorbic acid) and inactive (oxalic acid) metabolites. The therapeutic uses of ascorbic acid include prevention of ascorbic acid deficiency in patient at a risk and in infants, treatment of scurvy, in anaemia, to acidify the urine in urinary tract infection. They lower blood pressure and cholesterol level in the body. Also reduces the cold and has beneficial effect in the bacterial infection. Adequate amount of vitamin c intake may also prevent developing cancer of breast, cervix, colon etc.

We get vitamin $\mathrm{C}$ from the food particularly fruit and vegetables. Our bodies need vitamin $\mathrm{C}$ to make a substance collagen which is important for the health and repair of our skin, bones, teeth and cartilage. Vitamin $\mathrm{C}$ was first isolated in 1928. In 1932 it was proved to be the agent, which prevents scurvy. Scurvy is a diseased condition which occurs due to deficiency of vitamin $\mathrm{C}$ in the body. The common sources of vitamin $\mathrm{C}$ are citrus fruits and some other foods like tomatoes, broccoli, cauliflower, spinach, ladyfinger etc. The development of rapid, simple, and inexpensive analytical methods is one of areas of growing interest, especially since quick decisions are needed in environmental, medical, and industrial fields. Many analytical methods were used for ascorbic acid determination, including Titrimetric spectrophotometry and Chromatography, titrimetric, voltammetry, fluorometry, potentiometry as an analytical technique. Similarly, liquid chromatography capillary electrophoresis and gas chromatography were also used for the 
determination of ascorbic acid from different species of citrus fruits. UV Spectrophotometry is mostly used to determine ascorbic acid because it is simple method, and Vitamin C is able to absorb UV rays. The method is suitable for use with vitamin C tablets, fresh or packaged fruit juices and solid fruits and vegetables.

2,4 DNPH method of determining ascorbic acid content involves coupling reaction. This method is used in determining ascorbic acid content in different fruits and vegetables. 2,4 DNPH act as a dye in this method. In this method the total amount of vitamin C (Ascorbic acid + Dehydroascorbic acid) is determined in fruits by using UV spectrophotometer. Here bromine water is used which oxidizes the ascorbic acid into dehydroascorbic acid in the presence of acetic acid. Then known amount of 2,4 DNPH is added which gives coupling reaction. Solutions are kept for 3 hours. After 3 hours 85\% H2SO4 is added which gives coloured solution. These solutions are then measured for determining ascorbic acid content by using UV spectrophotometer.

\section{Materials and Methods}

Materials: 5\% Metaphosphoric acid-10\% acetic acid, 10\% Thiourea solution, 2,4-Dinitrophenylhydrazine solution, $85 \%$ Sulphuric acid

\section{Instrument}

i. UV- Visible spectrophotometer (Double beam) having matched quartz cells of light path $1 \mathrm{~cm}$.
ii. $\quad$ Model: Shimadzu 1800
iii. Software: UV probe Version of software: 2.42
iv. Electronic analytical weighing balance (REPTECH)
v. Volumetric flask (Borosilicate),
vi. Pipettes,
vii. Conical flask.

\section{Samples}

Star gooseberries, mulberry, karanda, black current, grapes, mango, guava, wax apple, muskmelon, watermelon, pomegranate, lemon (sweet lemon).

\section{Standard ascorbic acid solution}

Standard ascorbic acid solution was prepared by dissolving $50 \mathrm{mg}$ of AA in $100 \mathrm{ml}$ of distilled water. $(500 \mu \mathrm{g} / \mathrm{ml})$

\section{Preparation of calibration curve}

Calibration curve of different concentration i.e. $5,10,15,20,25 \mu \mathrm{g} / \mathrm{ml}$ was prepared by proper dilution method.

\section{Sample extract preparation}

Sample extract is prepared by blending $10 \mathrm{~g}$ of sample in the blender. Then sample was mixed with $50 \mathrm{ml}$ of $5 \%$ metaphosphoric acid acetic acid solution and transferred to the $250 \mathrm{ml}$ conical flask. Remaining amount of $50 \mathrm{ml}$ of phosphoric acid solution was added into the flask. Then the solution was filtered using Whatman filter paper and the filtrate was collected for determination of vitamin $\mathrm{C}$.

\section{Procedure for estimation of vitamin C}

To the filtered sample solution few drop of bromine solution was added and mixed. Then few drops of thiourea solution was added into the sample solution to remove access of the bromine solution.

Then $1 \mathrm{ml}$ of 2,4 DNPH solution was added to the sample solution and to all the standard calibration curve $(5,10,15,20,25 \mu \mathrm{g} / \mathrm{ml})$. Coupling reaction occurs due to $2,4 \mathrm{DNPH}$ solution. To complete the reaction all the standards and sample solution were kept at $37^{\circ} \mathrm{C}$ for 3 hours.

After 3 hours solutions were cooled on ice bath and $5 \mathrm{ml}$ of $\mathrm{H} 2 \mathrm{SO} 4$ was added. As a result, coloured solutions were obtained whose absorbance was measured at specific wavelength.

\section{Reaction}

i. Ascorbic acid is oxidized to dehydroascorbic acid by the action of bromine solution.

ii. L-dehydroascorbic acid reacts with 2,4dinitrophenylhydrazine and produces an osazone which on treatment with $\mathrm{H} 2 \mathrm{SO} 4$ forms red coloured solution.

Figure 1: Calibration curve of ascorbic acid. 


\section{Result and Discussion}

\section{Calibration curve}

After determination of $\lambda \max$ of coloured solution the absorbance of all the standards were taken to construct the calibration curve. The calibration curve was constructed by plotting absorbance versus concentration (Figure 1).

\section{Determination of vitamin C using UV- Spectrophotometer}

In this work for determination of vitamin $\mathrm{C}$ in fruits, fruits were fresh and collected from local market. Black current shows maximum amount of vitamin $\mathrm{C}$ and grapes shows minimum amount of vitamin C [1-15] (Table 1, Figure 2).

Table 1: Ascorbic acid content in fresh fruit by using UV Spectrophotometer.

\begin{tabular}{|c|c|c|c|}
\hline Sr No. & Sample & Biological Name & Amount of Vitamin C (mg/100gm) \\
\hline 1 & Star gooseberries & Phyllantus acidus & 8.29 \\
\hline 2 & Mulberry & Morus Nigra & 41.8 \\
\hline 3 & Karanda & Carissa carandas & 44.68 \\
\hline 4 & Black currant & Ribes nigrum & 446.83 \\
\hline 5 & Grapes & Vitis vinifera & 5.58 \\
\hline 6 & Mango & Magnifera indica & 36.41 \\
\hline 7 & Lemon & Citrus limetta & 56.4 \\
\hline 8 & Watermelon & Citrullus lanatas & 9.79 \\
\hline 9 & Muskmelon & Cucumis melo & 44.73 \\
\hline 10 & Wax apple & Syzygium samarangense & 18.89 \\
\hline 11 & Pomegranate & Punica granatum & 8.22 \\
\hline 12 & Guava & Psidium gujava & 181.79 \\
\hline
\end{tabular}

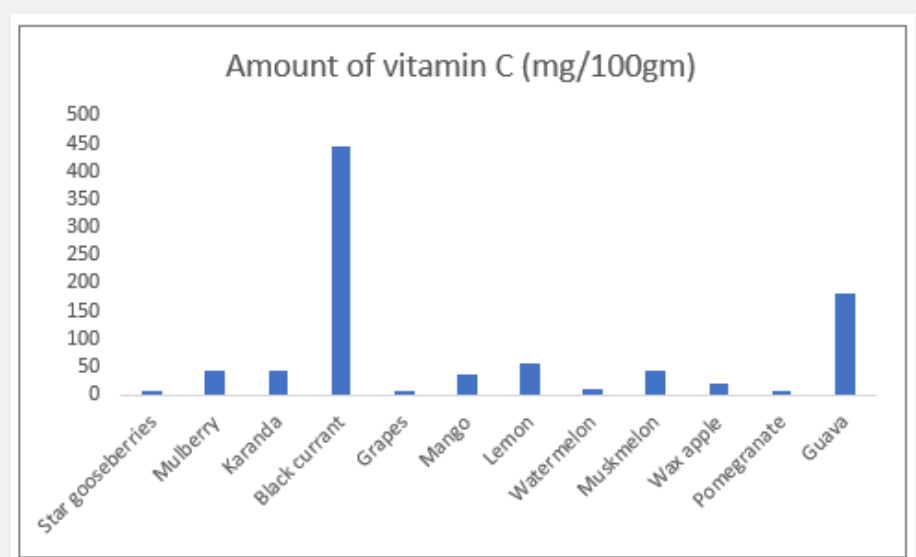

Figure 2: Ascorbic acid content in fresh fruit by using UV Spectrophotometer.

\section{Conclusion}

Spectrophotometric method for determination of vitamin C is simple and reliable method. The fruits which are taken from the local market are good source of vitamin C. This method $(2,4 \mathrm{DNPH})$ is simple and reliable and provide excellent result for determination of vitamin C. Black current shows maximum amount of vitamin $\mathrm{C}$ and grapes shows minimum amount of vitamin $\mathrm{C}$ among these samples taken.

\section{References}

1. Khan MMR, Rahman MM, Islam MS, Begum SA (2006) A simple UV spectroscopic method for determination of vitamin C content in various fruits and vegetables at Sylhet area in Bangladesh. Journal of biological science 6(2): 388-392.
2. Rahman MM, Khan MMR, Hosain MM (2007) Analysis of Vitamin C (ascorbic acid) Contents in Various Fruits and Vegetables by UVspectrophotometry. Bangladesh J Sci Ind Res 42(4): 417-424.

3. Tripathi KD (2013) Essential of Medical Pharmacology. ( $7^{\text {th }}$ edn), Jaypee Brothers medical publisher, New Delhi, India, pp. 909-918.

4. Hassan ALMMI, Hazim Y (2016) Determination of Vitamin C (ascorbic acid) Contents in various fruit and vegetable by UV-spectrophotometry and titration methods. JCPS 9(4): 2972-2974.

5. Santos DA, Lima KP, Marco PH, Valderrama P (2016) Vitamin C Determination by Ultraviolet Spectroscopy and Multiproduct Calibration. J Braz Chem Soc 27(10).

6. Sharma HL, Sharma KK (2013) Principles of pharmacology. ( $\left.2^{\text {nd }} e d n\right)$, Paras Medical Publisher, Hyderabad, India, pp. 667- 670.

7. Biswas SK, Mannan MA (1996) Determination of vitamin C (ascorbic acid) in some fruits and vegetables. B J Sci \& Ind Res: 1: 31. 
8. B Dinesh, Beerbin Yadav, R Deepak Reddy, A Sai Padma, MK Sukumaran (2015) Determination of Ascorbic Acid Content in Some Indian Spices. Int J Curr Microbiol App Sci 4(8): 864-868.

9. Deekshika B, Praveena Lakshmi B, Hemanth Singuluri, MK Sukumaran (2015) Estimation of ascorbic acid content in fruits \& vegetables from Hyderabad, India - A theoretical assessment of Vitamin C activity. Int J Curr Microbiol App Sci 4(1): 96-99.

10. Wintergerst ES, Maggini S, Hornig DH (2006) Immune-Enhancing Role of Vitamin C and Zinc and Effect on Clinical Conditions. Ann Nutr Metab 50(2): 89-94.

11. Ahmed MS, Mohammad JS, Noor J (2018) Spectrophotometric method for determination of vitamins. IJPSR 9(8): 3373-3378.
12. Varsha R, Padma NP (2017) Comparative Studies on Ascorbic acid content in Various Fruits, Vegetables and Leafy Vegetables. Int J of Life Sciences 5(4): 667-671.

13. Chaitanya S, Naga Padma P (2016) Stability Studies on Ascorbic Acid content in various fruits, Vegetables and their Cocktail Juices. International Journal for research in emerging science and technology 3: 35-39.

14. Elgailani IEH, Gad-Elkareem MAM, Noh EAA, Adam OEA, Alghamdil AMA (2017) Comparison of two methods for determination of vitamin $\mathrm{C}$ in some fruits. American Journal of Chemistry 2(1): 1-7

15. Chaney MS, Ross ML, Witschi, JC (1979) Nutrition. ( $9^{\text {th }}$ edn), Houghton Mifflin: Boston, MA, pp. 283-295

his work is licensed under Creative Commons Attribution 4.0 License

DOI: 10.19080/IJESNR.2019.21.556056 